\section{Epigenetics and genetic determinism}

\section{Epigenética e determinismo genético}

Hernán A. Burbano

Department of Biology, Universidad Nacional de Colombia

Ciudad Universitaria, Bogota - Colombia ilcelivago@yahoo.co.uk; haburbanor@unal.edu.co
BURBANO, H. A.: Epigenetics and genetic determinism.

História, Ciências, Saúde - Manguinhos, Rio de Janeiro, v. 13, n. 4, p. 851-63, Oct-Dec. 2006.

This paper posits that the gene-centered viewpoint of the organism (gene-centrism) is not enough to explain biological complexity. Organisms are not completely determined by their genomes; rather, living beings can be seen as interpreters or intentional systems. Epigenetics is the framework that allows the avoidance of gene-centrism and permits the emergence of a more holistic standpoint where determination and novelty can coexist, as shown with examples taken from developmental biology and macromolecules folding. In summary, as P. Medawar and J. Medawar wrote: "Genetics proposes; epigenetics disposes."

KEYWORDS: epigenetics; genetic determinism; gene-centrism.

BURBANO, H. A.: Epigenética e determinismo genético.

História, Ciências, Saúde - Manguinhos, Rio de Janeiro, v. 13, n. 4, p. 851-63, out.-dez. 2006.

O presente trabalho afirma que a visão geneticista do organismo (genecentrismo) não é suficiente para explicar a complexidade biológica. Os organismos não são completamente determinados por seus genomas; ou melhor, os seres vivos podem ser vistos como intérpretes ou sistemas intencionais. A epigenética é o arcabouço que ajuda a evitar o genecentrismo e permite a emergência de uma posição mais holística, em que determinismo e inovação podem coexistir, conforme demonstrado a partir de exemplos retirados da biologia do desenvolvimento e da estrutura das macromoléculas. Em resumo, como P. Medawar e J. Medawar escreveram: "A genética propõe e a epigenética dispõe".

PALAVRAS-CHAVE: epigenética; determinismo genético; genecentrismo. 


\section{The genetic-centered viewpoint of the organism (gene-centrism)}

\section{Schrödinger's book and its influence}

S chrödinger's What is life? (1944) is perhaps one of the most influential books in the origins of molecular biology; because of this, Lewontin (2001) has called Schrödinger the Rousseau of molecular biology. The aim of the Austrian physicist's work was the identification of the underlying order of the potentially inheritable molecules. He proposed that the macroscopic order of living beings arises from molecular order (microscopic order) and characterized the gene as an "aperiodic crystal." Schrödinger's book influenced the works of Watson and Crick and the emergence of molecular biology as a new scientific branch. Watson accepts that "Schrödinger was the first one I'd read to say that there must be a code of some kind that allowed molecules in cells to carry information" (Watson, 2003). Francis Crick acknowledges a similar but puzzling influence: "It's a book written by a physicist who doesn't know any chemistry. But ... it suggested that biological problems could be thought about in physical terms and thus it gave the impression that exciting things in this field were not far off" (quoted in Gould, 1995).

At the beginning of his seminal book, Schrödinger (1944) wrote: "We have inherited from our forefathers the keen longing for unified, all-embracing knowledge. The very name given to the highest institutions reminds us that from antiquity and throughout many centuries, the universal aspect has been the only one to be given full credit. ... We feel clearly that we are only now beginning to acquire reliable material for welding together the sum-total of all that is known into a whole."

According to Gould (1995), in the above quotation, Schrödinger expresses his agreement with unification as a goal of science. His belief was strongly influenced by the so-called "unity of science movement," a branch of logical positivism developed by the Vienna School during the 1920s and related to the Wiener Kreis. "The unity of science movement held that all sciences share the same language, laws, and methods, and that no fundamental differences exist between the physical and biological sciences, or (for that matter) between the natural and social sciences properly constituted" (Gould, 1995).

The unity of science movement was embedded within a larger cultural movement known as modernism; reduction, simplification, abstraction, and universalism were characteristics of this movement. Gould posits that modernism has, as any cultural movement, strengths and weaknesses. One of its major strengths is "its 
optimism and its commitment to mutual intelligibility based on unity of principles" (Gould, 1995). However, the same author highlights its weaknesses: "I deplore its emphasis [modernism] upon standardization in a world of such beautiful diversity; and reject the reductionism that underlies its search for general laws of highest abstraction" (Gould, 1995).

This is the social and cultural context that influenced Schrödinger's views of biological phenomenon, which were expressed in his What is life? This is the inheritance received by the "forefathers" that gave rise to molecular biology as a new science. This is the way the mainstream of evolutionary science understands what life is.

\section{The double helix and the fallacy of digitalism}

The image that arises when one thinks about the gene-centered view of the organism is undoubtedly Watson and Crick's double helix of the DNA polymer - the magic helix that holds the secret of life. According to Kemp (2003), the image of DNA is strongly associated with life and has become an icon that transcends biological sciences; in his own words: "History has thrown up a few superimages, which have so insinuated themselves into our visual consciousness that they have utterly transcended their original context. This is epitomized by the Mona Lisa, painted by Leonardo da Vinci around 1503. The double helix of DNA is unchallenged as the image epitomizing the biological sciences. Both images speak to audiences far beyond their respective specialist worlds, and both carry a vast baggage of associations."

Kemp (2003) also pointed out that the achievements of Watson and Crick are not of higher order than that of the other pioneers of molecular modeling, such as Braggs, John Kendrew, Max Perutz, Maurice Wilkins, and Linus Pauling. However, Watson and Crick "were uniquely fortunate that their molecule was both visually compelling, as a supreme example of nature's 'sculpture', and lay at the heart of the twentieth-century version of the quest to unravel the ultimate secret of life."

Seventeen years after the elucidation of the double helix, in 1953, Crick (1970) formulated the central dogma of molecular biology, where he proposed the direction of the information flow. Although the dogma has suffered substantial modification since its formulation, Hoffmeyer (2002) posits that, "for the practicing biologist, the central dogma always meant simply that 'instructions' were passed on from DNA to protein." One can say that the central dogma is instructional and "the temporal priority of DNA must also imply its causal priority" (Hoffmeyer, 2002); therefore, DNA determines the structure and function of biopolymers. 
Genetic determinism at the molecular level (there are genetic determinisms of a higher order) can be defined as the doctrine that assures that DNA contains all the coded information (necessary and sufficient) to specify the appropriate folding of a polymer (RNA or protein) and its structural or catalytic function. This definition emerges from Crick's central dogma and its underlying instructiveness.

From the molecular genetic determinism comes what Hoffmeyer (2002) has called the fallacy of digitalism: "the more or less automatic preference for explanations that ascribe primacy to digitally coded information or see such information as an explanation bottom line." These explanations have not been only applied at the molecular level; they also pertain to biological branches such as evolutionary and developmental biology. In the first case, evolution has been understood as "the gradual accumulation of sequential information inside the gene pools of evolving lineages" (Hoffmeyer, 2002). In the second, it is believed that ontogenetic development "is largely controlled by a digitally coded master plan for the regulated protein synthetic activity of the growing embryo" (Hoffmeyer, 2002).

Hoffmeyer (2002) pointed out that Crick used the term 'dogma' as a joke and not with its original meaning (theological doctrine authoritatively asserted). Nevertheless and paradoxically, "the central dogma did in fact attain the role of a dogma in a clerical sense, i.e., as a largely unquestioned or unquestionable ontological principle which served to legitimize biological digitalism" (Hoffmeyer, 2002). In the same sense and writing about molecular biology orthodoxy, Lewontin (2001) considers this central dogma as a Religion and the molecular biologist as its prophets.

Hoffmeyer (2002) gave his paper the title "The central dogma: A joke that became real."

\section{Epigenetics: from Waddington to modern biology}

Conrad Hal Waddington (1905-75) was a polymath scientist; he published research in paleontology, population genetics, developmental genetics, biochemical embryology, and theoretical biology. Due to his broad scientific interests, Slack (2002) asked himself if Waddington might be the last Renaissance biologist. He was the one who coined the term 'epigenetics', fusing the words 'epigenesis' and 'genetics'. In the mid-1960s, Waddington wrote: "Some years ago [i.e., 1947], I introduced the word 'epigenetics', derived from the Aristotelian word 'epigenesis', which had more or less passed into disuse, as a suitable name for the branch of biology which studies the causal interactions between genes and their products which bring the phenotype into being" (Jablonka and Lamb, 2002). Aristotle's theory of epigenesis stresses that developmental changes are gradual and qualitative. 'Epi' means 
'upon' or 'over', and the 'genetic' part of epigenetics implies that genes are involved, so the term reflected the need to study events 'over', or beyond, the gene (Jablonka and Lamb, 2002). Hall (1992) defines epigenetics as follows: "Epigenetics or epigenetic control is the sum of the genetic and non-genetic factors acting upon cells to selectively control the gene expression that produces increasing phenotypic complexity during development."

According to Jablonka and Lamb (2002), Waddington "saw the development in terms of what today we would call differential gene expression and regulation." Waddington "presented development as a series of branching decisions, taken under the control of genes .... and introduced the idea of 'epigenetic landscape' to describe the process of decision-making in development. The landscape refers to a surface on which a ball rolls down. At various points, there are branches in the possible path the ball can take, and so by the time it has rolled to the bottom, it will have made several binary choices. The ball represents a cell in an embryo and, at each developmental branch point, it is nudged down one path or the other by the action of embryonic inducing factors and/or homeotic genes (Slack, 2002).

It is interesting to see the forces that, according to Waddington, create the course, the slopes and cross sections of the valleys of the epigenetic landscape. He represented the genes and the chemical tendencies of the gene, respectively, as pegs and guy ropes underlying the landscape. Waddington tried to show that there is no simple (bijective) relationship between a gene and a particular phenotypic effect. If one gene is mutated, it will alter the tension of one rope but won't necessarily change the phenotypic effect because the valley suffers only slight modifications (Jablonka and Lamb, 2002). The valleys of the epigenetic landscape were called "chreodes" by Waddington ("buffered pathways in the landscape"; Slack, 2002). There is a process called canalization that avoids a radical change in the trajectory through the epigenetic landscape. In a Waddington glossary, Slack (2002) wrote about canalization: "a valley in the landscape represents a cluster of similar trajectories through state space. The idea of canalization indicates that most trajectories will exist as clusters; in other words, a small external or internal perturbation will not affect the pathway. ... Canalization or buffering is the outcome of natural selection for genes whose actions and interactions make the valleys in its epigenetic landscape deep and steep sided" (Jablonka and Lamb, 2002).

Jablonka and Lamb (2002) pointed out that epigenetics and developmental genetics are not the same. Developmental genetics studies the coupling between genetic and phenotypic variation, whereas epigenetics additionally wants to understand why very often genetic and phenotypic variations are not coupled. There are 
two main classes of non-coupled variation. The first occurs when a gene mutation or an environmental effect does not have any effect on the phenotype of an organism - this is the above discussed case of canalization. The other side of the coin is called plasticity, when genetically identical cells or organisms can differ in structure and function (i.e., a neuron and a liver cell or a worker and a queen bee).

Nowadays the situation is different, "since all developmental biologists tend to talk and think in terms of complex gene networks and interactions; the epigenetics perspective has, to a large extent, replaced that of classical developmental genetics." However, epigenetics is not the same as developmental biology; this is a much broader discipline that includes all aspects of embryology, regeneration, growth, and aging (Jablonka and Lamb, 2002).

\section{Macromolecules folding and information theory}

\section{Code duality and sequence and shape spaces mapping}

Hoffmeyer and Emmeche (1991) proposed that the central feature of living systems is what they called their "code duality" ("the ability of the system to represent itself in two different codes, one digital and one analog"). "Every life form exists both as itself, i.e., as an organism of 'flesh and blood', and as a coded description of itself, the latter being lodged within the remarkable DNA molecules of which the genetic material is composed. In short, the genetic material contains a coded version of the organism, almost in the same way a recipe from a cookery book contains an evening meal in the code" (Hoffmeyer, 1996).

The digital code (digital information) is a code for memory. "What should be specified through the memorized description is not the material details of the system, but only its structural relations in space and time" (Hoffmeyer, 2002). The digital information does not completely determine the phenotype (at any level); instead, an interpretation process is needed. A cheesecake will not be perfect just because the recipe is written in a cookbook; sometimes the result will be disastrous.

So we can say that what is alive, the organism, is different from what survives, the genetic material. It is the coded version, the genetic material, that is passed on to the next generation by means of procreation, while the organism must die. So what survives is in fact a code for something else, an image of the subject - not the subject itself. Life is survival in coded form" (Hoffmeyer, 1996). 
As already explained with the fallacy of digitalism, the scientific community has overestimated the importance of digital information. Richard Dawkins posits that genes are the units of selection and that organisms behave as robots (survival machines), obeying the orders of self-reproducing genes. On the other hand, Lewontin (2001) has pointed out that "first, DNA is not self-producing; second, it makes nothing; and, third, organisms are not determined by it." Although it is said that DNA produces proteins, it is the proteins (enzymes) that produce the DNA (Lewontin, 2001).

In summary, code duality is an argument against gene-centrism and is the philosophical ground that allows us to comprehend that there is more than genes determining the phenotypic outcome of an organism. There is something beyond the genes; there is something epigenetic.

Another important argument against the genetic-centered view of the organism is the mapping between sequence and shape spaces (for RNA molecules). The sequence space (or digital informational space) is "a mathematical representation of all possible sequences of fixed length that can be imagined by permutation of their basic symbols. ... The construction of a shape space (analog informational space) is an effort to formalize and represent all possible shapes or structural conformations that set of all chains of symbols of fixed length can attain, provided interactions between the constitutive symbols take place" (Andrade, 2002).

If genetic determinism is true, one expects to find a bijective (one sequence-one structure) relation in this mapping. However, the relation is definitely non-bijective; there is a many sequencesone structure relation and the shape space is smaller than the sequence space ( $10^{36}$ smaller for RNA). There is degeneracy in the mapping between digital and analogical informational spaces. Again, there is more than the genes determining and influencing the structure of a biopolymer.

\section{Information theory and biopolymer folding}

Adami (2004) posits that Shannon's information theory is an important and useful theory in the realm of molecular biology. Adami's standpoint steps away from the classical central dogma view and its underlying genetic determinism, which stresses that the sequence determines (has the complete information of) the threedimensional structure of the biopolymer (RNA or protein). Genetic determinism does not take into account the biochemical context (environment) where the folding process takes place.

Adami (2004), in order to avoid language problems, emphasizes that entropy and information are not the same thing. Shannon utilized both terms indiscriminately, whereas Adami stresses that 
entropy and uncertainty can be used interchangeably but he defines information in a way that coincides precisely with what we intuitively mean when we speak about information stored in genes.

According to Adami (2004), entropy or uncertainty is usually defined with respect to a particular observer. The entropy of a system represents the amount of uncertainty one particular observer has about the state of this system. Information can be understood as the difference between maximal entropy and remaining entropy after some knowledge about the system is gathered (through measurement or through the use of previous knowledge about the system). In a much broader sense, information measures the amount of correlation between two systems; there is not any information in a system where there is not any correlation, e.g., a gas under confinement in a closed system in thermodynamic equilibrium.

The information that a molecule (or a system) has about the other, or the mutual information content, is defined by the following equation:

$$
\mathrm{I}(\mathrm{X}: \mathrm{Y})=\mathrm{H}(\mathrm{X})+\mathrm{H}(\mathrm{Y})-\mathrm{H}(\mathrm{XY})
$$

The information that $X$ has about $Y$ (or $Y$ has about $X-$ information is a symmetrical quantity) is the difference between the sum of the entropies of each and the joint entropy (H (XY)). Figure 1.

Figure 1. Information that $X$ have about $Y$ (mutual information) (See text for details).

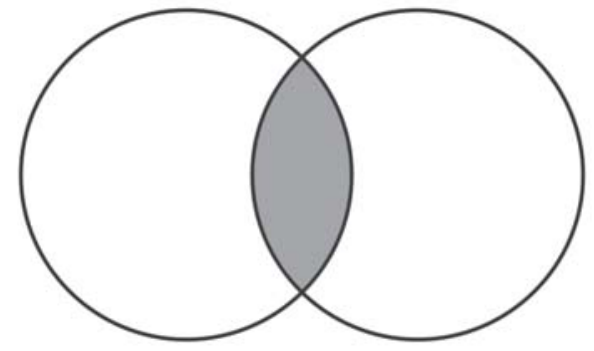

The left circle of figure 1 can be understood as the entropy of sequence $(H(X))$ and the right circle as the entropy of structure $(\mathrm{H}(\mathrm{Y}))$. The gray intersection represents the mutual information content (I) between $X$ (sequence) and $Y$ (structure). This information (the amount of this quantity) partially determines the three-dimensional structure of the molecule. If one circle completely overlaps the other, the genetic determinism doctrine will be true; however, this is an extreme and theoretical case. Environmental information comes into play during folding; this is a strong argument against genetic determinism. The environmental 
(biochemical context) information acquired by the molecule can be understood as epigenetic. "A process is epigenetic when it implies a structural development process where order emerges and there is differentiation and arising of functions that were not present in the constituent molecules" (Balbín, 2004). Natural selection favors sequences with a high content of mutual information; nevertheless, environmental information is always important for the folding outcome.

\section{Preformationism versus epigenesis}

\section{Historical and theoretical notes on developmental biology}

There have been two major tendencies during the history of developmental biology: preformationism (the final form of the organism is already present in the original matter) and epigenesis (the final form of the organism develops step by step). Philosophers like Seneca believed that all human body parts are already in the semen (as a little homunculus), whereas Aristotle was against the preformationistic doctrine and insisted that embryological development takes place gradually (step by step) (Aranda, 1997).

After the genetic revolution of the twentieth century, the old preformationism doctrine was transformed into modern preformationism, or neopreformationism (another example of genetic determinism); the homunculus inside the sperm or the egg has been replaced by the instructions stored in genes. The basic assumptions of modern preformationism are: (1) There is no dependence on initial conditions because all information is contained in genes. (2) There is no dependence on environmental (external) conditions. (3) The genetic information is necessary and sufficient for conducting the ontological process (Vega, 2004).

The followers of neopreformationism use the term gene in only one way. According to Moss (2002), there are two different gene concepts. The first is called Gene-P. We use it when we speak of genes for phenotypes (such as cystic fibrosis, blue eyes, or breast cancer). It follows the explanatory heuristics of preformationism in that it proceeds as if that which is transmitted is directly responsible for a phenotypic outcome, and so the ' $\mathrm{P}$ ' stands for 'preformationist'. Gene-P is defined with respect to phenotype but indeterminate with respect to DNA sequence (Moss, 2002). The second is called Gene-D. We use it when we speak of the NCAM gene, or the fibronectin gene, or the type IV collagen gene. Gene-D ('D' stands for developmental resource) is defined by its molecular sequence but is indeterminate with respect to its phenotypic consequence. Gene-D is consonant with the explanatory standpoint of epigenetics; it is always indeterminate with respect 
to phenotype because its phenotypic consequences are mediated by complex developmental and contextual factors (Moss, 2002).

Taking into account the above mentioned code duality, the ontological process can be seen as the translation from a digital to an analogical code, between genotype ("the whole genetic system of the zygote considered both as a set of hereditable units; that is to say, it includes not only the mere sum of genes, but also their arrangement, as expressed in position effects, translocations, inversions, etc." [Waddington quoted in van Speybroeck, 2002]) to phenotype ("the whole set of characters of an organism, considered as a developing entity" [Waddington quoted in van Speybroeck, 2002]). "The epigenetic translation process (from digital to analogical) brings about the ontogenesis of an organism" (Verhkavaara, 1998). This epigenetic translation is an interpretative process, and the interpreters are cells containing DNA code; in sexually reproducing species, the subject is the fertilized egg-cell (zygotes). "However, the zygote is only the 'first' subject (in multicellular organisms) - after cell-division, the proper subjects are descendant cells that are interpreting the same code (i.e., almost identical copies of the original DNA) in a different, multicellular environment" (Verhkavaara, 1998).

"Translation depends both on the interpreter's manner of translation (i.e., on the ontogenetically developed properties of the cell that are in principle historically unique), and on the context of interpretation (on environmental influence)" (Verhkavaara, 1998). This is an epigenetic explanation of cellular differentiation (plasticity), which occurs because of the differential expression (spatial and temporal) of the genes, and not because each cell has different genes.

\section{Nuclear transfer and genome reprogramming}

Cloning is an area in which epigenetics is important. It is clear that for normal development, the somatic nucleus that is utilized for cloning must be epigenetically reprogrammed. "The frequency of successful animal clones is still low, and many of the animals that manage to reach adulthood have abnormalities that can be attributed to aberrant reprogramming of the original somatic nucleus" (Jablonka and Lamb, 2002).

Epigenetic modification of the genome ensures proper gene activation during development and it involves: (1) Genomic methylation changes. (2) The assembly of histones and histone variants into nucleosomes. (3) Remodeling of other chromatinassociated proteins such as linker histones, polycomb group, nuclear scaffold proteins, and transcription factors (Rideaout et al., 2001). DNA methylation is perhaps the best-studied epigenetics modification of DNA in all unicellular and multicellular organisms. 
It is clear that in mammals there are developmental periods of genome reprogramming of methylation patterns in vivo (Reik et al., 2001). The two parental genomes are formatted during gametogenesis to respond to the oocyte environment and proceed through development. The zygote biochemically remodels the paternal genome shortly after fertilization and before embryonic genome activation occurs (Rideaout et al., 2001). According to Fergurson-Smith and Azím (2001), a consequence of genetic imprinting (a phenomenon that causes some genes to be expressed according to their parental origin and results in developmental asymmetry - epigenetic asymmetry - in the function of parental genomes) is that the mammalian oocyte is not truly totipotent, as a paternal genome is also essential for development.

The epigenetic conformation of any somatic nucleus is markedly different from that of mature gametes, and it is remarkable that the oocyte can reverse the epigenetic modifications imposed on the genome during differentiation to recreate a state of totipotency. The poor survival of nuclear clones could be due to genetic or epigenetic abnormalities; the most likely explanation of the developmental failure of nuclear transfer embryos is the inability to reprogram the epigenetic profile of the somatic donor nucleus to that of a fertilized zygote (Rideaout et al., 2001).

There is a spectrum of different outcomes to the reprogramming process, ranging from: (1) no reprogramming of the genome, resulting in immediate death of the nuclear transferred embryo, through: (2) partial reprogramming, allowing initial survival of the clones which results in an abnormal phenotype and/or lethality at various stages of development, as well as: (3) faithful reprogramming producing normal animals. The phenotypes observed in nuclear clones suggest that complete reprogramming is the exception (Rideaout et al., 2001).

Only a good understanding of epigenetics will allow the utilization of animal cloning as a powerful biotechnology tool.

Acknowledgments: I am grateful to Eugenio Andrade, Clara Spinel, and Juan Carlos Vega for valuable comments and a thorough reading of this manuscript. I am also indebted to Carlos E. Medina for his help in preparation of the English manuscript.

\section{Conclusion}

The genetic-centered view of the organism and its underlying genetic determinism were consolidated as the mainstream of biological science through the twentieth century. At the beginning of the twenty-first century, it is important to highlight that there is something 'Epi', something over or beyond genes, which makes the overestimation of digital information unable to answer the major questions of biological sciences, and means that organisms are not survival machines; instead, they are interpreters of their surroundings. As Medawar and Medawar (1988) have wisely pointed out: "Genetics proposes; epigenetics disposes." 


\section{BIBLIOGRAPHY}

Adami, Christoph

Andrade, Eugenio 2002

Aranda, A. 1997

Balbín, Oscar Alejandro 2004

Crick, Francis

1970

Fergurson-Smith

Anne. \& Azím, M. 2001

Gould, Stephen J. 1995

Hall, B. K.

1992

Hoffmeyer, Jesper 2002

Hoffmeyer, Jesper 1996

Hoffmeyer, Jesper

\& Emmeche, Claus 1991

Jablonka, Eva.

\& Lamb, Marion 2002

Kemp, Martin 2003

Lewontin, Richard 2001

Medawar, Peter.

Medawar, J. 1988

Moss, Lenny 2002

Reik, Wolf., Dean, Wendy. \& Walter, Jörn 2001

Rideaout, William, Eggan, Kevin. \& Jaenisch, Rudolf
Information Theory in Molecular Biology.

Physics of Life Reviews, 1, p. 3-22.

The organization of nature: semiotic agents as intermediaries between digital and analog informational spaces. SEED Journal (Semiotic, Evolution, Energy and Development) v. 2, n. 1, p. 56-84.

La complejidad y la forma. Mexico D. F.: Fondo de Cultura Económica.

Forma y epigénesis. In Ramírez, F., Balbín O. A., Betancourt-Morales, A., Mora-Oberlaender, J., Angel-Rodríguez, M., Vega, J. C. Biólogos lejos del equilibrio: nuevas metáforas evolutivas. Grupo de Biología Teórica. Bogotá. Universidad Nacional de Colombia, p. 107-25.

The Central Dogma of Molecular Biology. Nature, v. 227, p. 561-3.

Imprinting and epigenetic asymmetry between parental genomes. Science, v. 293, p. 1086-9.

¿What is life? as a problem in history. In M. P. Murphy y A.J. O'Neill (ed.), What is life? The next fifty years: speculations on the future of biology, Cambridge: CUP, p. 25-39.

Evolutionary developmental biology.

London, Chapman \& Hall (quoted in Jablonka and Lamb, 1992).

The central dogma: a joke that became real.

Semiotica, v. 138, n.1/4, p. 1-13.

Signs of meaning in the Universe.

Bloomington \& Indianapolis: Indiana UP.

Code-duality and the semiotics of nature. In Anderson, M., Merrel F.

(Ed.) On semiotic modeling. New York: Mouton de Gruyter, p. 117-66.

The changing concept of epigenetics.

Ann. N. Y. Acad. Sci., v. 98, p. 82-96.

The Mona Lisa of modern science.

Nature, v. 421, p. 416-20.

El sueño del genoma humano y otras ilusiones. Barcelona: Paidós.

De Aristóteles a Zoológicos: un diccionario filosófico de biología. México D.F.: Fondo de Cultura Económica.

From representational preformationism to the epigenesis of openness to the world?. Ann. N.Y. Acad. Sci., v. 981, p. 219-30.

Epigenetic reprogramming in Mammalian Development.

Science, v. 293, p. 1089-93.

Nuclear cloning and epigenetic reprogramming of the genome.

Science, v. 293, p. 1093-8. 
Schrödinger, Erwin ¿Qué es la vida?.

1997 [1944] Barcelona: Tusquets.

Slack, J. Conrad hal waddington: the last renaissance biologist?

2002 Nature Reviews Genetics, v. 3, p. 889-95.

Van Speybroeck, Linda From epigenesis to epigenetics: the case of C. H. Waddington.

2002

Ann. N.Y. Acad. Sci., v. 981, p. 61-81.

Verhkavaara, Tommi 1998

Extended concept of knowledge for evolutionary epistemology and for biosemiotics: hierarchies of storage and subject of knowledge In George L. Farre and Tarkko Oksala (ed.) Emergence, complexity, hierarchy, organization. Selected and edited papers from ECHO III. Acta Polytechnica Scandinavica: Mathematics, computing and management in engineering series, n. 91, p. 207-16.

Vega, Juan Carlos

Caos y ontogenia animal. In Ramírez, F., Balbín O. A., Betancourt-

Morales, A., Mora-Oberlaender, J., Angel-Rodríguez, M., Vega, J. C.

Biólogos lejos del equilibrio: nuevas metáforas evolutivas. Grupo de Biología

Teórica. Bogotá, Universidad Nacional de Colombia, p. 127-52.

Watson, James

A conversation with James D. Watson.

March 2003

Scientific American.

Submitted on April 2005.

Approved on November 2005. 